problem because there are liberal provisions for amendment to conform the pleadings to the proof. ${ }^{17}$ Duplicity is no longer fatal. ${ }^{18}$ Alternative allegations ${ }^{19}$ and prayers for relief ${ }^{20}$ are expressly protected by the Act. Many provisions of the Act and Rules give a reduced significance to the common-law conception of the "cause of action" and its pleading container, the count. ${ }^{21}$ The inflated use of multiple counts is in disfavor. ${ }^{22}$ Lastly, the Act expresses a definite policy of shortening trial litigation and eliminating pleading technicalities wherever pọssible, while continuing to do justice to all the interested parties. ${ }^{23}$

The abolition of the non-reference rule can benefit plaintiffs as well as defendants. A situation might arise in which a necessary averment has been inadvertently omitted from one count but is present in another. ${ }^{24}$ To permit the trial or appellate court to supply the missing averment would work no prejudice of surprise to the defendant, and would be in line with the provisions of the Act which permit liberal amendment by the trial ${ }^{25}$ and appellate courts, ${ }^{26}$ and which hold that objections not made at the trial cannot be raised on appeal. ${ }^{27}$

\title{
PRESCRIPTIVE EASEMENTS IN IILINOIS
}

The law relating to the establishment of easements by prescription generally requires the claimant of the easement to show that his use of another's land was open, exclusive, continuous and uninterrupted for the statutory period,

${ }^{17}$ Ibid., at $\$ 170(3)$.

18 Wattman v. St. Luke's Fospital Ass'n., 3 I4 III. App. 244, 4r N.E. 2d 3 I $_{4}$ (I942); Kovar v. Bremer, 28I Ill. App. 505 (I935), rev'd on other grounds 294 MII. App. 225, r3 N.E. 2d 656 (I938).

19 IIl. Rev. Stat. (I947) c. Iro, § I67 (2).

20 Tbid., at $\$$ I58.

${ }^{21}$ Ill. Rev. Stat. (I947) c. Iro, $\S$ I48 (3) (alternative claims against different defendants permitted in the same or separate counts); ibid., at $\$ 167$ (2) (alternate statements of fact permitted in the same or separate counts); ibid., at $\$ \$ 259.10$, 259.11 (certain equitable and legal matter permitted in one count or in separate counts); ibid., at $\S 259.12$ (different breaches of the same duty "growing out of the same transaction, or based on the same set of facts" permitted in one count, as well as in separate counts).

22 See Fisher, The Persistence of Chitty, 6 Univ. Chi. L. Rev. 359 (I939).

${ }^{23}$ Ill. Rev. Stat. (1947) c. I10, $\$$ I 28 ("This Act shall be liberally construed, to the end that controversies may be speedily and finally determined according to the substantive rights of the parties. ..."); ibid., at $\$ \S 1822$, 259.23 (pre-trial procedure); ibid., at $\$ \S \mathrm{x} 8 \mathrm{I}, 259.16$ (summary judgments).

${ }^{24}$ Compare, Lake Shore \& Michigan Southem Ry. v. Hessions, I 50 Ill. 546, 37 N.E. 905 (1894), where an allegation of survival of widow and next of kin appearing in the seventh count was held to apply to the first six counts, which charged different items of negligence.

25 IIl. Rev. Stat. (I947) c. Iro § I7o.

${ }^{26}$ Ibid., at $\$ 2$ I6 (a).

${ }^{27}$ Tbid., at $\S 166$ (3). 
and adverse to the servient landowner's interests. ${ }^{1}$ Adverse use may be demonstrated by evidence that the claimant asserted a "claim of right" to maintain the use which was inconsistent with the property interests of the owner. ${ }^{2}$ The burden of coming forward with such evidence generally falls upon the claimant; ${ }^{3}$ his failure to present evidence of adverse use would be fatal to his case. Not infrequently, neither party offers sufficient evidence to establish the adverse or permissive nature of the use. Rather than allow the usual allocation of the burden of coming forward with evidence to work against the claimant, many courts have recognized a rebuttable presumption of adverse use if the claimant has satisfied the other prerequisites for the establishment of an easement by prescription. ${ }^{4} \mathrm{~A}$ few courts, on the other hand, indulge in a presumption, also rebuttable, of permissive use. ${ }^{5}$ For the parties involved, the consequences of the adoption of one of these presumptions in a jurisdiction may be considerable. ${ }^{6}$ While most states have a well-settled rule as to which presumption, if any, will be applied, the Illinois decisions have not been consistent as to the quantum of proof necessary to establish adverse use. The recent case of Poulos v. F. H. Hill Co., however, crystallizes a definite trend toward adoption of the presumption of adverse use.

${ }^{1}$ Rest., Property $\$ \S 457,458,459$ (I944); 4 Tiffany, Real Property $\$ \S$ Ir95-97, I I99, I20I, I202 (3d ed. I939).

2 I Thompson, Real Property § 4I9 (1939); 4 Tiffany, Real Property $\S$ I I96, II97 (3d ed. I939).

${ }^{3}$ I Jones, Evidence $\$ 178$ (4th ed. I938).

' I Thompson, Real Property $\$ 436$ (x939); 4 Tiffany, Real Property $\$$ I x96a (3d ed. 1939).

${ }^{6}$ Speight v. Anderson, 226 N.C. 492, 39 S.E. 2 d 37 I (1946); Weber v. Gerber Holding Co., I38 N.J. Eq. 544, 49 A. $2 d$ doo (I946); Bowles v. Chapman, I80 Tenn. 32I, I75 S.W. 2d 313 (r943); Northwest Cities Gas Co. v. Western Fuel Co., I3 Wash. 2d 75, 123 P. 2d 77r (1942); Gowen v. Swain, 90 N.H. 383 , то A. 2d 249 (r939).

- When no presumption is recognized, the claimant must not only come forward with evidence of a claim of right but must assume the risk of nonpersuasion of the trier of facts. The defendant may succeed without producing contrary evidence if the claimant has not carried the burden of persuasion as to the facts claimed. The proponent of any fact must offer sufficient evidence of that fact so as to make it appear more likely than not that those facts are true.

When a presumption of adverse use is operative, the claimant may succeed without presenting any actual proof of adverse use if the landowner has not presented adequate rebuttal evidence. For the landowner to prevail, he must first overcome the presumption with actual proof in an amount and intensity which varies according to the rule of rebuttal adopted by the individual jurisdiction. See Morgan, Further Observations on Presumptions, I6 So. Calif. L. Rev. 245 (1943).

Sometimes evidence which is "credible" is sufficient to rebut; often "substantial evidence" is necessary, or evidence which makes the existence of the alleged fact more likely than its nonexistence, and occasionally "clear and convincing" proof is required to rebut a presumption. If there is a presumption of permissive use, the claimant likewise is required to produce actual evidence of adverse use sufficient to rebut the presumption. The claimant bears the burden of persuasion, which generally includes any evidential requirements of rebutting a presumption of permissive use. That is to say, once a claimant satisfactorily carries the burden of persuasion he will of necessity offer enough proof to rebut a presumption working against him. See note II infra.

${ }^{7} 4$ Or IIl. 204 , 81 N.E. $2 \mathrm{~d} 854$ (rg48). 
Early Illinois cases indicated that a claimant would not be aided by a presumption of adverse use but would be required to prove all elements necessary to the establishment of an easement by prescription. ${ }^{8}$ Some Illinois decisions, moreover, appear to have placed a heavier burden upon the claimant than is ordinarily required of the party who bears the burden of persuasion. ${ }^{9}$ These cases required the claimant to present sufficient evidence of adverse use to negative the possibility of the use having been permissive. This bordered on a requirement of clear and convincing proof of adverse use, a burden of persuasion more stringent than if the claimant were required simply to prove his case unaided by any presumption. ${ }^{10}$ Whether the Illinois courts recognized a presumption of permissive use, which the claimant would have to rebut, was not particularly significant since the rather heavy burden of persuasion on the claimant would have engulfed any incidental requirement of rebutting such a presumption. ${ }^{11}$ Where, however, the use originated in vacant, unoccupied, and unenclosed land, the Illinois cases have been uniform in asserting their adoption of the presumption of permissive use. ${ }^{12}$ Only unfenced land with no structures upon it seems to be included in this category.

It was not until Rush v. Collins ${ }^{13}$ that the Illinois Supreme Court started a definite trend toward adoption of the presumption of adverse use in instances where the use did not originate in vacant and unenclosed land. ${ }^{14}$ In that case, the claimant proved all the elements necessary to establish a prescriptive easement, including some evidence of a claim of right and recognition of that right

8 Parker v. Rosenberg, 3 I7 Ill. 5 II, I48 N.E. 269 (I925); Bontz v. Stear, 285 Ill. 599, I2I N.E. I76 (Igr8); Illinois Central R. Co. v. Stewart, 265 Ill. 35, ro6 N.E. 5 I2 (IgI4). Butsee Warren v. Jacksonville, I $_{5}$ IIl. 236 ( 1853 ).

- Waller v. Hildebrecht, 295 Ill. Ix6, I28 N.E. 807 (I920); Gilfoy v. Randall, 274 Ill. I28, II3 N.E. 88 (x9I6); Chicago, Burlington \& Quincy R. Co. v. Ives, 202 Ill. 69, 66 N.E. 940 (I903); Rose v. City of Farmington, I96 IIl. 226, 63 N.E. 63I (Ig02).

${ }^{10}$ See 9 Wigmore, Evidence $\$ 2498(3)$ (I940). Clear and convincing proof is often required in civil cases which involve fraud, undue influence, proof of contents of a will, proof of certain oral agreements, etc.

11 Brown v. Henderson, 285 Mass. I92, I89 N.E. 4I (I934); Board of Water Commissioners of New London v. Robbins, 82 Conn. 623, 640, 74 Atl. 938, 945 (I9IO); Lisbon v. Lyman, 49 N.H. 553, 563 (1870); Morgan, Presumptions, 12 Wash. L. Rev. 255, 27 I (1937). In Worth v. Worth, 48 Wyo. 44I, 49 P. 2 d 649 (I935) the court felt that the jury should be told of a presumption favoring the defendant although the plaintiff already had the burden of persuasion.

12 Carter Oil Co. v. Welker, 24 F. Supp. 753 (III., I938); Parker v. Rosenberg, 3 I 7 Ill. 5 Ir, I 48 N.E. 269 (1925); Waller v. Hildebrecht, 295 Ill. Ir6, I28 N.E. 807 (1920); Illinois Central R. Co. v. Stewart, 265 Ill. 35, 106 N.E. 512 (I9I4).

${ }^{13} 366$ Il. 307,8 N.E. 2 d 659 (1937).

${ }^{14}$ In cases involving claims of easements for public ways there have been decisions recognizing a presumption of adverse use. Mudge v. Wagoner, 320 Ill. 357, I5 I N.E. 276 (1926); Thorworth v. Scheets, 269 III. 573 , IIO N.E. 42 (I9I5). However, there also exist cases requiring actual proof of a claim of right in this field. Gietl v. Smith, 320 Ill. 467, I5 I N.E. 253 (r926) (decided the same day as Mudge v. Wagoner, supra); Doss v. Bunyan, 262 Ill. IOI, IOA N.E. I53 (x914). 
by the landowner. Although it recognized the sufficiency of this evidence of adverse use, the court chose to state further:

Where a way has been used openly, uninterruptedly, continuously and exclusively for more than a period of twenty years, the origin of the way not being shown, there is a presumption of a right or grant from the long acquiescence of the party upon whose land the way is located. This presumption of a grant or adverse right is prima facie merely and may be rebutted. In the absence of evidence tending to show that such long-continued use of the way may be referred to a license or other special indulgence, which is either revocable or terminable, the conclusion is, that it has grown out of a grant by the owner of the land, and has been exercised under a title thus derived.15

To explain the reason for this presumption, the court added:

The law favors this conclusion, because it will not presume any man's act to be illegal. It is also reasonable to suppose that the owner of the land would not have acquiesced in such enjoyment for so long a period, when it was his interest to have interrupted it, unless he felt conscious that the party enjoying it had a right and a title to it that could not be defeated. Because it can work no injustice to any one, except to him who has been guilty of great negligence, public policy and convenience require that this presumption should prevail in order to promote the public peace and quiet claims....16

Although this language was not essential to the Rush decision, it now appears to embody the prevailing Illinois rule, having been cited with approval in all subsequent cases involving prescriptive easements in Illinois. ${ }^{17}$

In the principal case, Poulos v. F. H. Hill Co. ${ }^{18}$ the origin of the use upon

${ }^{15} 366$ Ill. $307,315,8$ N.E. 2 d 659, 662-63 (1937).

${ }^{26}$ Ibid., at 315,663 .

${ }^{27}$ In Monroe v. Shrake, 376 Tll. 253, 33 N.E. 2 d 459 (194r), the origin of the use was in vacant, unenclosed land and therefore presumptively permissive. The claimant's showing that he had maintained and repaired a roadway across the land was not considered sufficient to rebut the presumption. But referring to Rush v. Collins, 366 Ill. 307,8 N.E. 2 d 659 (r937), the court suggested that had the use originated in occupied land, a prima facie presumption of right or grant from the landowner's long acquiescence might well have been found. Similarly, in Lang v. Dupuis, 382 Ill. ror, 46 N.E. $2 \mathrm{~d} 2 \mathrm{I}$ (1943), the court repeated the language of Rush v. Collins, supra, in regard to the presumption of adverse use, but did not apply it to the decision since proof of the existence of a license precluded a finding or a presumption of adverse use. In Leesch v. Krause, $393 \mathrm{IIl}$. I24, 65 N.E. $2 \mathrm{~d} 370$ (I946), the origin of a way across neighboring farm land was undetermined. Following the direction indicated in Monroe v. Shrake, supra, the court stated that it would presume a right or grant from the use of the pathway. There was evidence, however, that the claimant's predecessor had broken the lock of a gate preventing access to the way, and that the claimant had graveled the roadway with the landowner's knowledge. Utilizing the kind of evidence which, in the past had been insufficient to prove a claim of right, the tribunal was able to find an easement without relying upon the presumption of adverse use. The easing of the amount of proof required to sustain a claim of right may well be the direct consequence of the recognition of the presumption of adverse use. The presumption plus some evidence makes for a strong case in the absence of substantial rebuttal evidence.

${ }^{18} 40$ I Ill. 204 , 8I N.E. 2 d 854 (I948). 
improved urban property was unexplained, giving rise under the doctrine of the Rush case, to a presumption of right upon showing of open, continuous use. ${ }^{19}$ Although this presumption was acknowledged, there was also convincing proof of a claim of right: namely, the servient owner's compliance with the claimant's orders to remove all objects which would interfere with enjoyment of the use. As is generally the case, the court preferred to rely upon some actual evidence of the presumed fact, in conjunction with the presumption, rather than utilize the presumption alone in order to find that fact. Consequently, in no case of record in Illinois has a naked presumption of adverse use been employed to satisfy the requirement of a showing of a claim of right. But the language of the Rush case appears to have been accepted by the court. Should a case arise in which there is no evidence of a claim of right, the presumption of adverse use would undoubtedly be sufficient to satisfy the claimant's burden in the absence of adequate rebuttal evidence.

The amount of evidence required to rebut a presumption of adverse use has not yet been determined by the court. Illinois cases dealing with rebuttal of other presumptions of fact have held, generally, that upon introduction of evidence contrary to the presumption, which if believed would justify a finding against the presumption, the presumption vanishes and all the evidence goes to the trier of facts for consideration. ${ }^{20}$ Thus the Illinois courts appear to follow the Thayer-Wigmore view of rebuttal which is most lenient towards the party opposing the presumption. ${ }^{21}$

The Illinois view that there is a presumption of adverse use where all the other elements necessary for an easement by prescription are shown and where the origin of the use is not in vacant, unenclosed land, is the majority rule. ${ }^{22}$ Underlying this rule is the assumption that no man will allow another to enjoy an easement in his land if he can help it, since an easement is a detrimental burden upon the land. Consequently, if one man does make such use of another's property, the lack of objection on the owner's part can be attributed to the owner's inability to defeat the claim or to his own neglect. ${ }^{23}$ Because of procedural difficulties in the common law, earlier courts had employed the

${ }^{19}$ For a discussion of the advisability of applying the presumption of permissive use originating on vacant, unenclosed, unoccupied land to urban property, see Shepard v. Gilbert, 2I2 Wis. I, 249 N.W. 54 (I922) and Presumption as to Adverse Character of User of Way over Unenclosed Urban Land, I9 Corn. L.Q. 337 (I934).

${ }^{20}$ Osborne v. Osborne, 325 Ill. 229, $x_{5} 6$ N.E. 306 (I927); Sheldon v. Brandstetter, 325 Ill. App. 595, 6o N.E. 2d 576 (I945); Nielson v. Pyles, 222 Mll. App. 574, 54 N.E. 2d 753 (1944).

${ }^{21} 9$ Wigmore, Evidence $\S 249 \mathrm{I}(3)$ (I940); Mcrgan, Further Observations on Presumptions, 16 So. Calif. L. Rev. 245, 247 (I943).

${ }^{22}$ I Thompson, Real Property $\S 436$ (I939); 4 Tiffany, Real Property $\S$ II96a (3d ed. I939). For a collection of cases in each jurisdiction, see annotation $x 70$ A.L.R. 776 (I947).

${ }^{23}$ Rush v. Collins, $3^{66}$ Ill. 307, 315, 8 N.E. 2d 659, 662 (r937). 
fiction of a lost grant to justify finding an easement. This fiction has generally been discarded as a result of modern possibilities for establishing easements by application of the statute of limitations which designates the prescriptive period. ${ }^{24}$

The rationale behind the majority rule may not always represent the realities of modern society, but the effect is not undesirable. It places a reasonable time limit on the landowner's right to protest against a use, origin of which is not determined. After a lengthy period of maintaining the use, the dominant owner should be given assurance that he may continue his usual practice without disturbance. Application of the statute of limitations and the presumption of adverse use accomplishes this end.

In Poulos v. F. H. Hill Co. ${ }^{25}$ the plaintiff-owner of a vacant lot in Chicago desired to improve his property by constructing a three-story building. This construction would have been interfered with by a fire escape attached to an adjoining seven-story building owned by the defendant. The fire escape extended two and one-half feet over the plaintiff's land, was about twenty feet long, and ran from the top of the building to a point twenty feet above the ground where there was an attached hinged ladder which could be lowered onto the plaintiff's land below. This encroachment originated in Igr4 when the plaintiff's lot was improved with buildings long since razed. Although the fire escape had never been used, objects placed beneath it had been removed upon complaint of the defendant's manager. In a suit to compel removal of the fire escape, the defendant claimed that an easement had been acquired by prescription giving him both the right to maintain the fire escape and the right to use an unencumbered area below for lowering the ladder. The trial court recognized an easement to maintain the overhanging fire escape, but restricted the prescriptive right to the fire escape's unlowered level, twenty feet above the adjoining property. On appeal, the Illinois Supreme Court, after discussing the presumption of adverse use, found an easement to maintain the overhanging structure

\footnotetext{
24 The early English statute of limitations for establishing title by adverse possession was not applied to easements because it was held that incorporeal heraditaments could be gained only by grant. Therefore the courts invented the "lost grant" which became an irrebuttable presumption upon proof of the operative facts. This presumption of a lost grant of easemens was adopted by American courts, and many of them still speak in terms of this fiction. Others, recognizing that an easement may be established by prescription without need of a grant, have discarded the fiction for a simple application of the statute of limitations. Where there it no statute specifically prescribing a prescriptive period for easements, as in Illinois, the statutory period which applies to adverse possession is also applied to prescriptive easements. Those courts indulging in a presumption of adverse use upon a showing of the other elements necessary to establish an easement by prescription, sometimes speak of a presumed grant or title to justify the presumption of adverse use itself. This seems an unnecessary application of the ancient reasoning to allow finding one of the elements of an easement rather than the easement itself. In regard to the evolution of prescriplive easements and related presumptions, see Cheshire, Modern Law of Real Property, 254-67 (5th ed. I 944); 7 Holdsworth, History of English Law 343-52 (I926); 4 Tiffany, Real Property § II9I (3d ed. I939).
}

${ }^{25} 4$ or Ill. 204,8 I N.E. 2 d 854 (I948). 
and to use that portion of the space and ground immediately below where the hinged ladder would descend.

Recognition of an easement to maintain an overhanging structure, in the present case, establishes precedent on a point of law which had not previously arisen in Illinois. ${ }^{26}$ The result is in accord with decisions in other jurisdictions that such a right may accrue to the owner of an object which protrudes over, but does not touch the adjoining land. A common example is the extension of eaves or of cornices of a roof. ${ }^{27}$ Other possibilities are window shutters, ${ }_{2}^{28}$ awnings, ${ }^{29}$ signs, flag poles, ${ }^{\natural}$ wires and antennae. Easements to continue an underground encroachment also have been recognized, ${ }^{30}$ but overhanging shrubbery or limbs of trees have failed to give rise to an easement. ${ }^{31}$

After finding an easement to maintain an overhanging structure, the court in the instant case was confronted with the further problem of ruling as to the claimant's right to use the surface of the land beneath the protrusion. This problem perhaps could have been solved by interpretation of the general rule that one who has an easement created by prescription also has the privilege of doing such acts as are necessary to make effective the enjoyment thereof, unless the burden upon the servient land is thereby unreasonably increased. ${ }^{32}$ Since most easements gained by prescription are rights of way, the scope of the additional use is usually limited to the making of repairs and improvements and to increasing the use of the way. By analogy, the owner of a protruding structure who has a prescriptive right to maintain it, may enter upon the servient land to make repairs and improvements. The servient landowner has the privilege of using his property in any way not incompatible with the use

${ }^{26}$ In Jobst v. Mayer, 327 IIl. 423 , I58 N.E. 745 (r927) and Finch v. Theiss, 267 Ill. 65 , 107 N.E. 898 (I915), the Illinois Supreme Court enjoined the maintenance of fire escapes extending over private ways. Had these encumbrances been maintained for twenty years, the dominant owners might have acquired easements by prescription.

${ }^{27}$ Romans v. Nadler, 2I7 Minn. I74, I4 N.W. $2 \mathrm{~d} 482$ (I944) (eaves and dripping gutters); J. C. Vereen \& Sons v. Houser, I23 Fla. 64I. I67 So. 45 (I936) (protruding eaves); Matthys v. First Swedish Baptist Church, 223 Mass. 544, II2 N.E. 228 (I9I6) (extending roof); Sorkin v. Sentman, I62 $\mathrm{Pa}$. 543, 29 Atl. 722 (1894) (attic protruding over adjoining property); Grace M. E. Church v. Dobbins, I53 Pa. 294, 25 Atl. II20 (1893) (overhanging comice).

${ }^{28}$ Homewood Realty Corp. v. Safe Deposit \& Trust Co., I60 Md. 457, I54 Atl. 58 (I93I).

${ }^{29}$ In Jobst v. Mayer, 327 Ill. 423, I 58 N.E. 745 (I927), maintenance of an awning protruding over complainant's private way was enjoined. If it had been maintained for the prescriptive period, an easement could have been established.

${ }^{30}$ Sorkin v. Sentman, $\mathrm{I}_{2} \mathrm{~Pa}$. 543, 29 Atl. 722 ( 1894 ) (cellar beneath surface of adjoining land); Bass v. Gregory, 25 Q.B.D. $48 \mathrm{I}$ (I8go) (airshaft through adjoining building beneath the surface); Koenigs v. Jung, 73 Wis. I78, 40 N.W. 801 (I888) (underground vault).

${ }^{31}$ Robinson v. Clapp, 65 Conn. 365,32 Atl. 939 (I895); Lemmon v. Webb, [I894] 3 Ch. x. In the case of old trees which do not continue to grow but maintain the same position in relation to the servient land for the prescriptive period, under a claim of right and with servient landowner's acquiescence, a contrary result would seem likely.

32 Rest., Property § 480 (r944); x Thompson, Real Property \$§ 449, 450 (I939). 
authorized by the easement. ${ }^{33}$ Therefore, where the dominant owner has the right to maintain an overhanging structure, the right of the servient owner to build upon the land below the protrusion depends upon the necessity of free access to that land by the dominant owner for maintenance and enjoyment of the easement. ${ }^{34}$

The court in the Poulos case held that the right to maintain a use for a particular purpose must carry with it all the peculiar uses inseparably related to effective enjoyment of the easement. ${ }^{35}$ Maintenance of an unencumbered area beneath the fire escape in this case was so related, even though there had been no previous occasion for the use of the fire escape and therefore no reason to enter upon the ground beneath. Denial of the owner's right to construct a building beneath the protrusion was thus recommended by the practical necessities of the situation. Recognizing an easement but permitting it to be rendered useless-the import of the lower court's decision-would have been a futile gesture.

All easements, including an easement to maintain an overhanging structure, represent a right in the servient land. The court in the present case seemed to imply that maintenance of a fire escape with a hinged ladder so located was in effect a use of the surface below as well as the space actually occupied. If that is so, the potentiality of the use thus was a use, and therefore the "potentiality" should be guaranteed by prescription as well as the continued maintenance of the encroaching structure. The decision thus introduces a new concept of the type of use which may ripen into an easement by prescription. Future application of this concept, however, will probably be restricted to closely similar situations where failure to recognize the right to the complementary use would render the easement valueless.

${ }^{23}$ Doan v. Allgood, 3 ro Ill. 38r, I4I N.E. 779 (I923); Finch v. Theiss, 267 Ill. 65, I07 N.E 898 (I9I5); Rest., Property \$48r (I944).

${ }^{34}$ In Dunbar v. O'Brien, II 7 Neb. 245,220 N.W. 278 (I928), the claimant acquired the right to enter upon a vacant strip of land on the adjoining property beneath claimant's overhanging eaves for the purpose of painting his house, washing windows and making repairs. The easement extended beyond the area covered by the eaves because of the necessity of having room to place ladders. But in Romans v. Nadler, 217 Minn. $174, x_{4}$ N.W. 2d 482 (1944), a similar claim failed because the plaintiff did not enter upon the adjoining land to make repairs more often than every six years. In the cases cited, the prescriptive right to enter upon another's land beneath claimant's overhanging structure was based upon periodic entry for the purpose of maintaining or repairing the easement property. In the absence of such entry to the land beneath the fire escape, in the Poulos case, the right to an easement in such land had to be determined on other grounds.

${ }^{35}$ Whether the claimant in the Poulos case had the right to ingress and egress across the servient land to the spot where the escape ladder would rest when lowered was not determined because the question was not raised in the pleadings. The principle announced, however, would seem likely to extend the easement that far. 